\title{
The Cooperative Movement in Kenya: Women Only Cooperatives Their Potential for Women's Empowerment and Enhancement of Gender-Just Peace
}

\author{
Mildred Jenifer Lodiaga* \\ Department of Sociology, Gender and Development Studies, Kenyatta University, Kenya
}

*Corresponding author: Mildred Jenifer Lodiaga, Department of Sociology, Gender and Development Studies, Kenyatta University Kenya.

To Cite This Article: Mildred Jenifer Lodiaga, The Cooperative Movement in Kenya: Women Only Cooperatives Their Potential for Women's Empowerment and Enhancement of Gender-Just Peace. 2020 - 7(4). AJBSR.MS.ID.001177. DOI: 10.34297/AJBSR.2020.07.001177.

Received: 眥 January 27, 2020; Published: 眥 February 26, 2020

\begin{abstract}
This paper is based on a review of secondary sources from academic articles. It describes how women owned and managed cooperatives hold potentials to empower women and to transform gender relations and as a path to achieving gender-just peace goal. Peace and social well-being are embedded within the cooperative movement's core values and principles. The paper suggests how cooperatives can and do effectively promote economic and social inclusion, a factor that can enhance elimination of friction among different social groups. This is because cooperative societies bring together various classes of people regardless of their socio- economic status as their agenda would be one only-"to share ideas, suggest and implement viable practices that are likely to bring development and uplift economic and social status of members". For women the common bond would include sisterhood. The argument put forward is that cooperatives are powerful vehicles of social inclusion, political and economic empowerment of their members. The principles upon which the cooperative movement is built could harness awareness regarding the power of cooperatives particularly those owned by women in not only improving livelihoods but also making inroads by creating a conducive environment for gender -just peace. By challenging gender power relations, they hold potential to transform gender relations. The paper suggests how cooperatives can effectively prevent economic and social exclusion, a factor that can enhance friction among different social groups. The paper focuses on assessing the role of co-operative societies in empowering the women and changing the traditional powerbase in societies where they operate.
\end{abstract}

Keywords: Cooperative; Gender; Gender Relations; Gender Just Peace; Empowerment; Power.

\section{Introduction}

Women are 52 per cent of the population of Kenya (Kenya National Bureau of Statistics, 2019 Census), but they have unequal access to economic, political, social and cultural opportunities. Great strides have been made towards gender equality over the last few decades. Despite this fact, deep gender disparities persist across the globe, surfacing in labour markets, as well as other realms. Compared to men, women continue to earn less, are more likely to partake in unpaid labour, and are more likely to be excluded from decent work and opportunities for advancement. According to UN Women's recent statistics on the progress of the world's women, only 50 per cent of women, compared to 77 per cent of men, are employed and of those employed women, receive 10 to 30 per cent less in wages than their male counterparts (UN Women, 2015).

Women also face occupational segregation, both by being over-represented in services, housework, and agricultural work and by encountering the "glass ceiling" - in which men and women have the same occupation, but men enjoy more responsibilities, better pay, and higher status regardless of skills or experience (ILO, 2012b). Women also have less access to education, have less mobility, have less access to financial institutions, and are viewed as dependents (ILO, 2012b). Human rights violations continue unabated in the forms of intimate partner violence, sexual violence, human 
trafficking, female genital mutilation and child marriages. Women and girls also experience gender-based violence in different parts of the world. Violence against women and girls manifests itself in physical, sexual and psychological forms. Whether at home, on the streets, during war, violence against women and girls is a human rights violation of pandemic proportions that takes place in public and private spaces. (UN Women, 2019). It is estimated, that of the 87,000 women who were intentionally killed in 2017 globally, more than half (50,000- 58 per cent) were killed by intimate partners or family members, meaning that 137 women across the world are killed by a member of their own family every day (UN Women 2019). In Africa, Majority of women are employed in agriculture where productivity and incomes are low. Many of those employed outside agriculture are in the informal sector where jobs are vulnerable and incomes low with gender wage disparities.

The gender gaps in all these areas are even wider in North Africa, the Middle East, South Asia, and Sub-Saharan Africa (World Economic Forum, 2014). As gender equity is increasingly seen as a pillar for sustainable economic development and broad social well-being, alternative models to development which incorporate women's equality is seriously necessary in all aspects.

Women's empowerment was adopted as one of the main agendas for the international community in 1995 at the Beijing Conference, (UN Women 2015). The adoption of the Beijing Declaration and Platform for Action at the Fourth World Conference on Women in 1995 laid the foundation for action towards gender equality in all aspects of economic, social, cultural and political life. Twenty years later, the International Labour Organization (ILO) and the International Co-operative Alliance (ICA) have joined to assess how one sector the co-operative movement is impacting (and is impacted by) progress towards women's empowerment and gender equality (ILO, 2015). Rooted in values of self-help, equality, and equity, as well as economic growth through cooperation and democratic processes, the cooperative therefore can serve as alternative for women who have traditionally been disenfranchised by the formal financial system due largely to the undue disadvantages brought on them by socio-cultural and economic institutions.

Gender was in the spotlight at the 24th Session of the African Union Heads of States' Summit held in Addis Ababa, Ethiopia from 30-31 January 2013, which focused on the "Year of Women's Empowerment and Development towards Africa's Agenda 2063". Africa 2063 agenda Goal 14 emphasizes full gender equality in all spheres of life. To attain this goal, African countries would have to address the following priority areas and indicative strategies:

Empowered women and girls and provide equal access and opportunity in all spheres of life, end all forms of violence and discrimination (social, economic and political) against women and girls and ensure full enjoyment of all their human rights
The components of Africa 2063 agenda included elimination of all forms of violence and discrimination (social, economic, political) against women and girls. If violence and discrimination would have been eliminated, women and girls would have been eliminated and they would fully enjoy all their human rights. The Africa of 2063 would see fully empowered women with equal access and opportunity in all spheres of life. The UN Sustainable Development Goal 5 to achieve gender equality and empower all women and girls. This adoption of gender equality and women's empowerment priorities signals the global recognition that improving the lives of women and girls are both important development goals in themselves and key to the success of all the other goals to achieve sustainable development. The term gender equality refers to an ideal state in which women are receiving and gaining access to the same benefits (stable employment, income, safe working conditions, leadership roles, and social mobility) as men [1]. As Bill and Melinda Gates (2019) put it.

We recognize the importance of intentionally focusing on power relations and inequality ...If we do not seek to understand and address power imbalances and inequality, we risk reinforcing them". ... A focus on empowerment requires a shift away from seeing women and girls as beneficiaries or objects ... to viewing them as agents of change for their own individual and collective empowerment. Beyond providing resources or benefits, programs that aim to empower women and girls must involve a process of social transformation, ultimately enhancing the control that women and girls have over their own lives.

From the above citations the question is - Why is there so much emphasis on women's empowerment and gender equality?

\section{What is empowerment?}

The word empowerment comes from the word power. What then is power and why does it matter? The literature reviewed indicate that there are four dimensions of power namely:

\section{Power over}

Which refers to when one or more people act to constrain significantly the choices of one or more other people (it includes oppressive domination) Power over is how power is most understood [2]. It is power built on force, coercion, domination and control [2] and motivated largely through fear. It is power built on a belief that power is a finite resource that can be held by individuals, and that some people have power and some people do not. This understanding include power being regarded as a 'zero sum game'. The other forms of power recognize that power is not owned by individuals but is a dynamic, which is present in every relationship. As Starhawk (1990) suggests:

Power is never static, for power is not a thing that we can hold or store, it is a movement, a relationship, a balance, fluid and changing. 
The power one person can wield over another is dependent on a myriad of external factors and subtle agreements (p. 268).

\section{Power within}

It has to do with individual agency, beliefs about oneself: the capacity to aspire, self-efficacy, self-worth, self-esteem, dignity, autonomy, resolve. (Bill and Melinada Gates 2019, Pritchett and Kapoor 2009, 131). This type of power is related to a person's "sense of self-worth and self-knowledge; it includes an ability to recognize individual differences while respecting others" (VeneKlasen L, \& Miller V (2007). p. 45). Power within involves people having a sense of their own capacity and self-worth. Power within allows people to recognize their "power to" and "power with", and believe they can make a difference (VeneKlasen L \& Miller V (2007). In the words of Bruyn and Rayman:

To create the conditions whereby power can be shared. The purpose is to create the conditions in which everyone's opportunity to exercise power is maximized in the context of the larger community (Bruyn $S$ \& Rayman P (Eds.) (1979 p. 21).

"Power is in having and being. Some people see power as only having. Some people see power as something internal, my values, my abilities"(Pritchett and Kapoor 2009, 131).

\section{Power To}

Is for an individual to have the capacities and resources to attain valuable ends. (Narayan et al. 2000, 240) Power to refers to the "productive or generative potential of power and the new possibilities or actions that can be created without using relationships of domination" [2]. It is built on the "unique potential of every person to shape his or her life and world" (VeneKlasen L \& Miller V (2007 p. 45 ). It is the power to make a difference, to create something new, or to achieve goals.

\section{Power with}

(Group Power) is the collective agency of a group to attain valuable ends. It includes solidarity, collective action or mutual support. (Bill and Melinada Gates 2019; Narayan-Parker 2005, 17). Power with is shared power that grows out of collaboration and relationships. It is built on respect, mutual support, shared power, solidarity, influence, empowerment and collaborative decision making. Power with is linked to "social power, the influence that is wielded among equals" (Starhawk (1990). Power with can help build bridges within groups (e.g., families, organisations, social change movements) or across differences (e.g., gender, culture, class) (VeneKlasen L \& Miller $V$ (2007). Rather than domination and control, power with leads to collective action and the ability to act together Berger BK (2005), Starhawk (1990), VeneKlasen L \& Miller V (2007) [2-4].

The last three dimensions of power are about changing the systems, institutions, and mindsets that perpetuate patriarchal hierar- chies of power (power over) and existing social order."

Definitions of empowerment can be gathered into two major classifications (Alsop et al. 2006). The first one considers empowerment as an expansion of agency: agency, in turn, is the ability to act on behalf of what you value and have reason to value Ibrahim and Alkire 2007) [5]. The second definition of empowerment focuses on the social and institutional preconditions required to exert agency Alsop and Heinsohn 2005) [6]. This is the approach followed by the World Bank in the 2000-2001 World Development report where empowerment is defined as a process of 'enhancing the capacity of poor people to influence the state institutions that affect their lives, by strengthening their participation in political processes and local decision-making.' Similarly, Narayan (2002) defines empowerment as an 'expansion of assets and capabilities of poor people to participate in, negotiate with, influence, control and hold accountable institutions that affect their lives.

The term empowerment has drawn further criticism for implying that an external force bestows empowerment upon a woman diminishing her own power and agency. Wilson (2008) argues that the empowerment from outside approach can in fact victimize and disempower local women and hinder work for deeper transformations of existing power structures as the women are reduced to mute, passive subjects awaiting rescue. Among feminists it is generally accepted that women's empowerment is something that has to come from within the women themselves (Rowlands 1995). Practically, for women in this movement, empowerment means coming together as part of a community to articulate their specific needs and concerns in order to work out how best to act.

Women's empowerment has five components namely:

women's sense of self-worth; their right to have and to determine choices; their right to have access to opportunities and resources; their right to have power to control their own lives, both within and outside the home; and their ability to influence the direction of social change to create a more just social and economic order, suitable for their own survival.

In this context, education, training, awareness raising, building self-confidence, expansion of choices, increased access to and control over resources, and actions to transform the structures and institutions that reinforce and perpetuate gender discrimination and inequality are important tools for empowering women to claim their rights.

\section{What is Gender Just Peace?}

Creating a world of gender equality and gender justice means building collective power (power with) rather than dominating power (power over). It means creating a world where people and planet can flourish without discrimination. (Kabeer 1999). Peace is about women and men and how they relate to each other. Gen- 
der and peace are closely linked: peace is vital to promote gender equality, while gender inequality can also undermine peace and generate conflict and promote violence. Is gender-just peace possible given the deep-rooted patriarchal gender regimes that determine women's multiple subject positions? What are the parameters of a gender-just peace? [7]. argues that in order to build a genderjust peace, dis-empowering patriarchy and engaging with the feminist agenda of empowering women must be the guiding principle for all peace initiatives.

According to Mannergren et al (2014) gender just peace should be understood as "a positive peace that provides for social justice and equity" which "contributes to a fundamental shift in the provision of specific rights related to women's gender roles, a transformation of gender relations in society, and redefinition of gendered hierarchies"[8]. Since gender is not solely women (Kronsell 2012) as cited by (Björkdahl and Selimovic 2015 p. 168), and to avoid "losing out on the dynamic relations of power between the identities of women and men that the concept of gender entails", this paper "employ[s] gender as a concept that more broadly informs an understanding of power, exclusion, and marginalization" (Björkdahl \& Mannergren Selimovic 2015: 168).(Rahel Weideab Sebhatu 2017).

Gender-just peace is far from a reality in any country. To achieve gender -just peace it will be necessary to empower women socioeconomically by pushing women's (in)formal responsibilities to the public sector; and to improve the participation and representation of women in higher positions in the cooperatives as well. Gender equality is the number one predictor of peace - more so than a state's wealth, level of democracy, or religious identity. Do cooperatives have the potential to change the traditional power base or challenge social power relations in society by empowering women through their participation in cooperatives especially women owned cooperatives? If so, what are the potentials? The study considers whether co-operatives are and can be a good organizational structure for encouraging and supporting gender equality and women's empowerment and consequently create gender just peace in society. What are the potentials for women's co-operatives in empowering women and creating gender just peace? Peace and social well-being are embedded within the cooperative movement's core values and principles and encompass what is distinctive about co-operative ideology and identity. Co-operatives are based on values of equality and equity that constantly strive to rise above differences of ethnicity, religion, politics, and gender. They posit a commitment to solidarity with others based on a common humanity and for women a common sisterhood. Those values are the basis of co-operative principles, are a key source of co-operative effectiveness; they provide an endless, evolving context within which co-operatives can work for better understandings and mutual aid among all kinds of people. (Yahuda Paz 2015) Values are tools for making life work well, and co-operatives are tools for achieving a mission that serves both its members and much more.
A statement of values, and seven principles comprise the Identity Statement of a cooperative. The basic cooperative values as enshrined in the Statement are:

'Cooperatives are based on the values of self-help, self-responsibility, democracy, equality, equity and solidarity. In the tradition of their founders, cooperative members believe in the ethical values of honesty, openness, social responsibility and caring for others.'

Are cooperatives well placed to do this? There is a perception that co-operatives should achieve gender equality and women's empowerment purely because of the cooperative principles. What are the potentials of women owned cooperatives as change agents? Are they geared towards minimizing animosities in resource allocation/distribution, control and access of resources; challenge traditionally accepted gender power relations and contribute to the building of a gender -just peace society? Potential Impact of Cooperatives can be seen through its values and principles which serve as guiding blocks.

This paper examines five of the seven principles of cooperatives that ought to guide the formation, organization and activities of cooperatives as:

a. Voluntary and open membership

b. Democratic member control

c. Member economic participation

d. Autonomy and independence

e. Education, training and information

f. Cooperation among Cooperatives

g. Concern for Community.

The above seven principles encompass the elements of basic tools of women empowerment cited earlier in the paper. They make several distinctions about cooperation as discussed in the sections that follow. This brief provides insights into questions such as: How can cooperative enterprises help promote gender equality? What are ways women can make use of the cooperative advantage to access opportunities that are otherwise denied to them? In what follows, an attempt has been made, to investigate how participation in a woman only cooperative can have direct impact or spillover effect in other domains of women members' lives by examining each of the above principles.

\section{Status of Cooperative Movement in Kenya}

The cooperative movement in Kenya is vibrant and dynamic and it is the strongest in Africa. It is a key player in the economy, controlling about 43 per cent of Kenya's gross domestic product (GDP). The Cooperative Societies in Kenya employs more than 300,000 people, besides providing opportunities for self-employment to many more. Savings and Credit Societies (SACCOs), the fast- 
est growing sub-sector in the movement, have mobilized savings of more than Kshs 230 billion or 2.3 billion dollars (Cooperative, 2011/2012 Yearbook). The total number of societies and unions rose by 7.3 per cent from 13,256 in 2010 to 14,228 in 2011. Overall, a total of 972 additional cooperative societies and unions were registered, with almost half of these being savings and credit societies, with membership standing at more than eight million Kenyans. Kenya boasts about 15,000 registered cooperatives with 12 million members. There are more than 320,000 employees and a further 1.5 million people engaged in small scale and informal enterprise funded by cooperative loans. The movement provides two million jobs with 70 per cent of Kenyans depending directly or indirectly on cooperatives.

To safeguard the gains achieved this far, the Government has taken various measures to ensure the movement operates according to international best practice. These include the establishment of the Sacco Societies Regulatory Authority (SASRA) through the Sacco Societies Act 2008, which introduced prudential regulations covering all deposit taking Saccos to enhance transparency and accountability in the fast-growing sub-sector. It is anticipated that the move will also spur economic growth through mobilization of domestic savings. Kenya and South Africa are the only countries in Africa with independent regulators and specific regulations for Saccos - the Sacco Societies Act and Co-operative Banking Act, respectively. Kenya's cooperative sector is reputed to be one of the most regulated in Africa and the best in East Africa.

Despite the advantages of the model, in the majority of African countries, Kenya included, women remain under-represented as both employees, members and in particular leaders of cooperatives. For instance, COOPAFRICA research reveals that in Ethiopia, only $18 \%$ of cooperative members are women and, and in Uganda, a 55-cooperative survey covering Area Cooperative Enterprises (ACEs) showed that women constitute 33\% of board members, $13 \%$ of chairpersons, and $12 \%$ of managers. Achieving active and equal participation of women - for instance, being able to access benefits such as technical services or education as members, or being able to influence decision-making and shape the cooperative's agenda as leaders - which is not revealed by statistics, is an even greater challenge.

However, it should be pointed out that the cooperative movement in Kenya indicates the cumulative figures in the register at the office of the Commissioner of Cooperative Development, does not tell how many cooperatives are active, dormant or deregistered. It should be noted that the figures exclude what have been referred to as "pre-cooperatives" or unregistered cooperatives that may be operating in Kenya. Since cooperatives in Kenya are only recognized after registration, it may not be possible to establish the number of unregistered cooperatives and their membership.

There are numerous cooperative-like organizations in Kenya that go by the name 'community-based organizations', which in- clude women's groups, youth groups and savings and credit associations. It has not been possible to qualify the number of these organizations in Kenya as many of them are not formally registered. The Department of Gender reported that there were 138,753 registered women's groups with a membership of 5,417,850 in 2007 (Republic of Kenya 2008a: 64). The current status is unknown as the figures given are not disaggregated by activity level, membership level or multiple memberships. This indicates tremendous growth over the past years.

\section{Potentials for The Co-operative Development Model in changing the existing/traditional power base in societies.}

\section{Principle One: Voluntary and Open Membership}

Status of Women in Mainstream cooperatives: The role of co-operatives in reducing poverty and fostering human development has been increasingly acknowledged in the academic literature (Sen 2000, Birchall 2003, 2004; Bibby and Shaw 2005, Münker 2012; Vicari and De Muro 2012, Vicari 2014) and by international institutions (FAO et al., 2011 United Nations 1992-2013). The emphasis has been placed especially on co-operatives performing according to the principles and values identified by the International Co-operative Alliance (ICA) in 1995. In 2002, the International Labour Organization Recommendation No. 193 on the Promotion of Cooperatives Recommendation that explicitly states: "special consideration should be given to increasing women's participation in the cooperative movement at all levels, particularly at management and leadership level". According to the first cooperative principle on voluntary and open membership, women should be able to enjoy the same services and accept the same responsibilities as men within a cooperative. However, despite the supposed democratic structure and the values and benefits shared by cooperative members, due to negative cultural instilled practices and gender norms, women suffer a disproportionately low representation in cooperative membership around the world, Kenya, included. Women tend to be shut out of leadership and decision-making positions in mainstream cooperatives, and often do not benefit to the same extent as their male counterparts.

The literature available on the topic shows that women are still insufficiently represented in mainstream co-operatives. This is manifested in terms of representation through active membership (showing up to meetings and voting), leadership and managerial positions and as employees, limited access to assets and education (Rawlings and Shaw 2013) [9]. A study carried out by the ILO found that cooperative laws are "gender neutral» and do not directly discriminate against women. However, in reality laws intended to protect women are ignored in favor of cultural norms or are maneuvered around. Most legal barriers to women's cooperative membership are largely indirect and written into cooperative by laws. Mayoux, $(1992,1993,1995)$ points out that co-operatives do not 
automatically operate in favour of more gender-balanced relations: they can contribute to it only if they are able to challenge power structures and the unequal division of labour, which are usually transmitted across generations. In the mainstream cooperatives the situation exists where people could "participate" in a project without having the power to decide on the critical issues to that project. Empowerment is supposed to bring closer those who hold the power and those who are powerless. Empowerment moves the powerless into positions of power and makes those at the highest level of power accept sharing power with them.

In Kenya because we do not have adequate gender disaggregated data, and reliable statistics, many co-operatives often reflect the same power relations of the society as most women are found in the lower echelons as cooperatives members and are not in decision making positions that are male-dominated. Studies have shown factors such as traditional roles, cultural practices and norms that gives privilege to men, gender neutral or blind legal frameworks, which favors men at the expense of women. However, the possibility of women influencing men to begin paying attention to gender issues through platforms created by mainstream or mixed co-co-operatives is not envisaged soon. This is because as noted by FAO, IFAD and WFP (2012) factors hindering women's active participation in cooperatives are often structural and backed by socio-cultural norms at the household and community levels. These culturally erected structures often leave women with weakened self-esteem, which prevents them from participating in decision-making roles in the society as well as in the mainstream cooperatives where they are members. What then is the alternative for women? As stated by the ILO, "women-only co-operatives may help overcome social and cultural constraints which might otherwise limit women's participation". Women's cooperatives, founded, designed, run by and composed entirely of women, may be structured in a way that makes them easier for women to fully participate.

Women's Only Cooperatives: In many developing countries women work individually, often isolated, in the informal economy, operating at a low level of activity and reaping marginal income. Joining forces in small-scale cooperatives can provide them with the economic, social and political leverage they need. Like other cooperatives, women have formed cooperatives to address the needs of families of diverse cultures, ethnic, religious, economic, political and professional backgrounds. The co-operative principles are guidelines by which co-operatives put their values into practice" (United Nations, 1996; Ban, 2009; ICA, 2015b). The women's co-operative literature indicates the growing interest in co-operatives founded, designed and run by women, and for women (Ibourk and Amaghouss 2014; Russell-DuVarney 2013; Sapovadia and Patel 2013).

A co-operative, as Chambo (2009) defines it, is an organization formed by people with a specified common problem, and the mem- bers of the co-operative pool resources together by contributing to building assets for the co-operative. Women's cooperatives are often built on ideas of sisterhood, equality, and strength from unity [10]. How many of such cooperatives do we have in Kenya? Currently statistics are not available. What potentials do exist for the cooperative model for women members? What is the potential impact of these co-operatives for the Kenyan women cooperators?

First, Membership is open and voluntary and that they are member-owned and controlled businesses, in which all members have an equal say in the governance of the business: each member has one vote regardless of the amount of wealth invested by the member. Because a cooperative is open to all women, old or young can enter whatever their social, racial, political or religious orientation. By widening ownership, co-operatives are a proven force for economic and social inclusion thus embracing the idea of unity in diversity hence hold potential for reduction of inequality. The common bond is what unites all the members. The members decide what unites them, this could be their occupation like farming, church, employment or where they live or in the case of women, because they share sisterhood.

In these circumstances, women only co-operatives enable women to have the necessary exposure, gain the skills and experience necessary to participate in larger co-operatives where restricting membership is a direct response to wider gender discrimination and disadvantage women face in society. Restricting membership to women only does not breach this first Principle (Alliance 2015). According to Yahuda Puz (2015), as long as co-operatives follow the principles of open membership and member engagement, and live up to the values the movement espouses, they will be agents for collaboration within communities, promoters of associative intelligence, and ambassadors of peace.

Secondly, at the heart of the cooperative values and principles, power means, "joining together with other people and acting by consensus" i.e. power with or group power. Women's empowerment is a fundamental and necessary obligation in order to achieve gender equality discussed earlier. Cooperatives are group-based ventures, members benefit by joining forces with others to be able to access economies of scale as providers of services or products or as consumers. Participating in a cooperative as a member, elected leader or manager also brings with its enhanced status, social capital and voice. Cooperatives, therefore, can allow women's empowerment through membership and participation as some assume different roles and responsibilities, as members they can engage not only on a social and economic level but also on a political one. Empowerment is the driving force behind giving co-operation a high potential for transformation. By definition, the term co-operation includes the meaning of empowerment: being aware of their capabilities; awareness of their abilities to develop and deploy resources, which allow them to take control of their future and their 
lives; and the capacity to identify, discuss and resolve issues to help them make decisions for their future and for their development as members of their cooperatives. The transformation of power relations occurs when women exercise agency and take action through expanded access to and control over resources and changes to the institutional structures that ultimately shape their lives and futures (Bill and Melinda Gates 2019).

Thirdly, participation in co-operatives can contribute to widening human choices and foster more equal gender relations, helping women exercise their human agency. More specifically, in patriarchal contexts, co-operative membership may contribute to increasing women's self-confidence and self-determination and their ability to make independent choices, enabling them to pursue what they value and have reason to value, not only in the workplaces, but more generally, in multiple domains of their lives (Ibrahim and Alkire 2007; Alkire 2009).

\section{Principle Two: Democratic Member Control}

Democracy is not as easy to define and measure as one might think. The Merriam-Webster online dictionary defines democracy as, "A government in which the supreme power is vested in the people and exercised by them directly or indirectly through a system of representation usually involving periodically held free elections at different levels. Women's co-operatives are often strategies in response to patriarchal labour market institutions, like mainstream cooperatives, where women may not be or feel welcome and heard. Women's only cooperatives make spaces that allow women to exercise their democratic decision-making without being discriminated against. This is critical to women's success towards dismantling patriarchal structures that limit their spaces. Democracy is not a passive right. It is a demand that members control their organization by active participation, and that each member should be held accountable for being active. Being a co-operative means that the common good of all is dependent on the conscious and meaningful engagement by all. The democratic nature of the cooperative does mean women members, like men, can have a stronger voice in the cooperative's matters than in other types of enterprises.

As mentioned earlier, opportunity for women to be in management and leadership positions is not possible in mainstream cooperatives. Literature indicate that, there are fears that women will not have the skills, knowledge and confidence to engage in board activities of mainstream cooperatives. However, in Kenya it is natural to equate men with leadership positions because this is how Kenyan communities have been run for centuries now. Traditionally, women lack a voice and have little access to leadership and decision-making because they are usually given a lower status than men in society. For this reason, participation by women in women-only co-operatives where they would be able to access leadership at all levels is an important opportunity. Participation in women owned cooperatives provide opportunity for women to be leaders through democratic member control. Women have been empowered to take up leadership roles, set up their own management committees and organize welfare activities and are able to create their own agency. Women themselves take up all managerial and administrative responsibilities: act as managers or administrative officers and this has the potential to change the way women as well as men have always viewed leadership and decision-making in the society.

Further, cooperative behaviour can foster changes in the power dynamics and could have a strong impact on the relational and individual dimensions of members' life. They have aggregated people who share the same needs and common interests, despite having limited resources, through democratic processes. Co-operatives, democratic and participatory enterprises can contribute to empowering and giving a voice to the women and being a means of collective human agency as individuals come together to pursue goals that they value and have reason to value (Ibrahim and Alkire 2007) [5].

Members elect cooperative leaders, managers, board members who are women and take key decisions about the organization through the system "one member one vote". This structure embeds values such as reciprocal trust and collaboration. Women come together either for the same scope, for new job creation, for the purchase of affordable goods and services, or for shared values such as collaboration and reciprocity rather than exploitation among agents (Sacconi \& Ottone, 2015) [11]. As women participate or get fully engaged in cooperative activities, they will have the opportunity to expand their aspirations, strengthen their voice, and exercise more choice. Expansion of choice and strengthening of voice entail a transformation of unequal power relations. Transformation of power relations occurs when women exercise agency and act through expanded access to and control over resources (Bill and Melinda Gates Foundation Methods Notes- Measurement notes (2019)). This is the vision of the Sustainable Development Goals (SDGs) five, a vision where no one is left behind, a vision of equality, where there is responsive, participatory and representative decision-making at all levels (Lakshmi 2016) [12-15].

\section{Principle 3. Members' Economic Participation, support or Creation of Commonwealth as well as increase in in- come}

A component central to the ideology of cooperatives is the notion of the Co-operative commonwealth and the creation of an alternative society where equal and affordable access to opportunity and equitable sharing of the benefits that discourages inequitable concentration of wealth. In cooperatives every individual contribution, whether in membership, capital or trade, is a voluntary contribution, which is a result of a free and willing decision made by an individual person. There is no coercion. Every such contribution is an advance toward the commonwealth. 
In Kenya, like other African countries, a woman's right to own, inherit and manage or dispose of her property was (and still is) subject to patriarchal practices. Traditional societies categorized women among a man's property. Moreover, even when societies started making strides towards modernity, anachronistic cultural practices continue to persist or subtly changed face, remaining innocuously with us.

It also is important to point out that women work two-thirds of the working hours, earn only ten per cent of the world's income, own less than one per cent of the world property and two-thirds out of the estimated 876 million adults worldwide who cannot read or write (FAO, 2010). Women constitute $70 \%$ of the world living in poverty and them only own $1 \%$ of all property. Women in Kenya are at a serious disadvantage when trying to access credit. However, most Microfinance Institutions (MFIs) view women (particularly rural women) as (ostensibly) a credit risk. When they manage to acquire loans, high interest rates averaging $10 \%$ per month are charged. It is therefore important for women to organize and form savings and credit cooperative schemes of their own from which they could borrow when in need and do away with the MFIs. Availability of microcredit loans does not automatically guarantee their access by women. Negative tactics are often used in loan recovery, in which group responsibility plays a large role and women's honor is publicly shamed if they default. The lack of economic opportunities for women creates economic dependence on their male relatives or friends. This makes a woman extremely vulnerable if something happens to their significant others such as brother, father or husband or to their marriage as women have few economic opportunities. Women only cooperatives offer a way out of these negative situations that microcredit puts women in due to the communal net and support that they provide through rough times. Furthermore, they allow women, who might have been isolated and working individually in the informal economy, to avoid loan defaults because they are able to join with other members to create economies of scale and increase their influence and bargaining power in the market [16-20].

The primary purpose of the cooperatives is to encourage savings among members from which they can borrow at affordable terms decided by themselves collectively or through the elected directors/ managers. Other financial services the cooperatives offer include Automatic Teller Machines (ATM), Mobile money transfer and custody of valuable documents. Cooperatives have also been successful in providing essential services like market access, storage and transport to members. Provided members with access to land, credit which is easily attainable because, as members they have a greater capability to meet the requirements of financial institutions and provision of non-financial services to members, giving them access to loans that have low interest rates without the requirement of collateral, sell to markets that they would not indi- vidually be able to access, and enhanced incomes using instruments that cannot be encroached-Mobile Phone Money Transfer Services known locally as M-pesa services. In the cooperatives, women can borrow depending on how much one has saved. Borrowing starts after six months of saving. Many are able to borrow and spend on activities that have economic value and returns for them. Things that matter to most women about their financial undertakings include convenience, security, privacy and reliability. Cooperatives offer these and more. Coops have the potential to liberate women economically and uplift their dignity.

Women's co-operatives can be a supportive, gender-specific organizational framework providing a safe environment for women to challenge patriarchal social norms related to decision-making and leadership (Russell-DuVarney 2013) [21-24]. By using the women's co-operative structure, women can be empowered economically.

The empowerment of women in the economic dimensions of the peacebuilding agenda is an investment useful for the whole community and the society at large. "Firstly, the extension of women's participation in employment and entrepreneurship strengthens the economy required for societal stability. Secondly, the economic independence of women contributes to their options for emancipation, which is a pre-requisite for a just and egalitarian society. Thirdly, such training builds women's confidence and capacity to challenge traditional power structures and exert pressure on decision-making processes, leading to a full role in the reconstruction of society. Empowerment means accepting and allowing people, women, in this case, who are on the outside of the decision-making process into it. People are empowered when they can access the opportunities available to them without limitations.

\section{Principle 4: Autonomy and Independence-Cooperatives are autonomous, self-help organizations controlled by their members}

The fourth principle makes it clear that democratic governance by the members is such a fundamental spart of cooperatives that it is not to be surrendered for any reason, even for business partnerships or capital. This principle is meant to remind all that cooperatives are not supposed to surrender their fundamental identity in order to get money or business partners. They do not serve any ideology whether defined by politics, religion or business theory. Cooperative is to provide goods and/or services to the member-owners who participate in it, and to do it in a manner consistent with the cooperative principles.

In line with the definition of co-operative as an autonomous association of persons unified voluntarily to meet their common economic, social and cultural needs through a jointly owned and democratically controlled enterprise, such an institution serve to address the disadvantaged position that women have found themselves in by mobilizing savings from members. The underlying 
dynamic is that cooperation, thrives on power-with (Power with describes collective power, when people come together for change and not power-over (direct and indirect control by one person or group over another person or group). Cooperatives provide an environment where women empower each other together. That is, co-operatives should have a transformative social and political role, not just a self-serving economic role.

While women's autonomy, traditionally, is conditioned largely by gender stratification and patriarchal authority in the society in which they live, education can increase a woman's autonomy. In cooperatives individuals find their autonomy, independence and individuality in the context of "others", which means to be responsible for groups interests. In patriarchal contexts, co-operative membership may contribute to increasing women's self-confidence and self-determination and their ability to make independent choices, enabling them to pursue what they value and have reason to value, not only in the workplace, but more generally, in multiple domains of their lives.

Autonomy defined as the capacity for a woman to achieve well-being and a role in decision-making. Autonomy is usually understood also as self-government or self-direction: being autonomous is acting on motives, reasons, or values that are one's own. The ability of women to make decisions that affect the circumstances of their own lives is an essential aspect of empowerment. Dimensions of women's autonomy includes outside mobility and access to economic resources. Co-operatives can contribute strongly to the spread of new knowledge, values and processes and bring about the meaningful empowerment of groups usually relegated to subordinate positions, women.

\section{Principle 5: Education, Training and Information}

Majority of women in developing economies do not have access to education, and many of those who do accessed lower levels of education. The low literacy levels have hampered women's ability to access information on support services that could improve their businesses, enable them to earn reasonable income and accumulate enough capital especially from formal institutions. Given such limitations, majority of these women are forced into the informal economy. In women's only cooperatives, adequate training is therefore necessary for ensuring that all members can fully participate in their cooperatives. It is particularly relevant for women, who may have to overcome social and cultural barriers and who may have previously been excluded from access to educational opportunities. Education is one of the most important means of empowering women with the knowledge, skills and self-confidence necessary to participate fully not only in cooperative but also in the development process (UNFPA 1994 ICPD - $7^{\text {Th }}$ Issue Women Empowerment, UNFPA [25-28].

It must be mentioned here that women only co-operatives, where membership is only open to women, do not breach the first
Principle where they are established to overcome gender discrimination and disadvantage. Such cooperatives can help create opportunities for women in training on co-operative business and management, the building of capital, and help overcome lack of gender equality in cultures where women are traditionally excluded from entrepreneurial and/or leadership positions and activities. Rules and responsibilities of membership must be understood, accepted and applied by members. A better approach to using legal norms as instruments for development is to empower the members, to inform them of their new rights and to encourage them to claim and defend such rights. The role of co-operative education is to develop co-operators, people who understand and share the values that underpin co-operation, understand the rights and responsibilities of membership, and how to apply those principles in their everyday life, thus helping to build a more co-operative society.

For women, involvement in women only cooperatives may mean much more - exposure to the public domain. The woman will be able to see herself not only as human capital but also cite her ability to invest in herself constantly through activities such as professional development - trainings, as technical skills improvement and management training, workshops , conferences as these will be seen as practices or activities that appreciate the value of the self. It is postulated that all these have the potential to erase the traditional notions of sexual differences and also the long standing divisions and political differences are likely to be erased and hence or in the long run the public and private divide are likely to collapse. Further, the distinction between a woman's private self and public enterprise is likely to diminish, as the self itself becomes an enterprise thus reducing traditional notion of dependence on male significant others. The underlying dynamic is that cooperation, wherever it occurs, thrives on power-with not power-over. Through their values, principles, and practices co-operatives encourage building capacity to bridge crippling divisions through the pursuit of specific, mutually beneficial, attainable goals. Cooperatives have served as schools of democratic action and empowerment for women starting typically with a young, timid, inexperienced housewife and taking her through confidence building states until many are capable of speaking before mass audience's and the end result being improved self-esteem and confidence [29-35].

\section{Principle 7: Concern for Community.}

At the Manchester Congress in 1995 when the International Co-operative Alliance adopted Principle Seven: Concern for Community, which encouraged co-operators and co-operatives to work for the sustainable development of the communities they serve. The bylaws also act as guiding principles that can influence people's way of handling problems in general. The women cooperators do not work and live in isolation but within their communities. Communities provides a powerful space because this is where attitudes can change about issues - changing the way men and women 
view leadership and decision making, gender power relations, access and control of resources traditionally viewed differently. The local community is a powerful space because it is where attitudes can change about issues that seem small in comparisons to the country's larger problems but are actually significant for changing the way men and women view leadership and decision making, power, access and control of resources. Competition over control of resources always cause conflict and threated peaceful coexistence of women and men in society. However, when communities are at peace there is justice. Hence Gender - Just Peace is realized [36-40].

\section{Conclusion}

Traditional gender relations exist within co-operatives, creating gendered power relations and hierarchies that discriminate against women members. The attitudes and the influence of leaders often reflect negatively on women cooperators. In Kenya, women are known to remain under-represented in the movement, meaning the "cooperative advantage" is not being used to its full potential to empower women. The cooperative sub sector in Kenya cuts across all sectors of the economy and is an area that may be exploited for strategies for Women Empowerment and Gender - Just Peace.

\section{References}

1. Kabeer, Naila (2005) Gender equality and women's empowerment: A critical analysis the third millennium development goal 1." Gender \& Development 13(1): 13-24.

2. Mathie A, Cameron J, Gibson K (2017) Asset-based and citizen-led development: Using a diffracted power lens to analyze the possibilities and challenges. Progress in Development Studies 17(1): 1-13.

3. Hunjan R, Keophilavon S (2010) Making change happen. Fife Carnegie UK Trust.

4. Graeme Stuart (2019) Sustaining Community, the Family Action Centre at the University of Newcastle.

5. Rowlands J (1997) Questioning Empowerment, Oxfam, Oxford, US.

6. Narayan D (2002) Empowerment and Poverty Reduction. A Sourcebook, Washington, US.

7. Yakin Erturk (2013) The quest for gender-just peace: from Impunity to accountability.

8. Björkdahl A, Mannergren Selimovic J (2014) Gendered Justice Gaps in Bosnia-Herzegovina Human Rights Review 15(2): 201-218.

9. Majurin E (2012) How Women Fare in East Africa Co-operatives: The Case of Kenya, Tanzania and Uganda, Dar Es Salaam: ILO.

10. Desouza Shaila (2012) The Strength of Collective Processes: An Outcome Analysis of Women's Collectives in India. Indian Journal of Gender Studies 19(3): 373-392.

11. Ostrom E (2012) The future of the commons: beyond market failure and government regulations. Institute of Economic Affairs, London

12. Abell H (2014) Worker co-operatives. Pathways to scale. Democracy Collaborative.

13. Adeler M (2014) Enabling policy environments for co-operative development. Acomparative experience 40(1): 50-59

14. Alperovitz G, Hanna T (2014) Mondragon and the system problem. In J Davis, T Hanna, L Krimerman, A Mcleod (Eds) Scaling up the cooperative movement. Retrieved from Democracy.
15. Alperovitz G, Speth J, Guinan J (2015) New political-economic possibilities for the $21^{\text {st }}$ century (NLP Report No. 1).

16. Awotide, Diran Olawale (2012) Assessment of Women's Participation in Cooperative Societies and its Determinants in Yewa North Local Government Area of Ogun State. Nigeri Asian Journal of Agriculture and Rural Development 2(3): 1-8.

17. Björkdahl A, Selimovic JM (2013) Advancing women agency in transitional justice $1(1)$.

18. Cathy Farnworth, Melinda Fones Sundell, Akinyi Nzioki, Violet Shivutse, Marion Davis (2013) Transforming Gender Relations in Agriculture in Sub-Saharan Africa. SIANI.

19. Clugston C (2014) The Business Case for Women's Participation in Agricultural Cooperatives. A Case Study of the Manduvira Sugar Cane Cooperative Paraguay. ACDI/VOCA.

20. COOPAC (2015) Policy Brief. Cooperatives, Women and Gender Equality in Committee for the Promotion and Advancement of Cooperatives (COOPAC) COOPAC Policy Brief.

21. European Institute for Gender Equality (2019) Women Empowerment.

22. Francesco Burchi, Sara Vicari (2016) The Co-Operative Firm Keywords. Andrea Bernardi and Salvatore Monni (Ed).

23. Fredrick, O Wanyama (2008) Surviving liberalization: the cooperative movement in Kenya Coop AFRICA Working Paper 10: ILO.

24. Giagnocavo Cynthia (2012) Civil Society, Cooperative Capacity Building and Eradicating Poverty.

25. ILO (2013) Promising Practices: How cooperatives work for working women in Africa. International Labour Organization pp.3.

26. Joy Emmanuel (2015) Concern for Community: The Relevance of Cooperatives to Peace. Ian MacPherson, Yehudah Paz (Ed) pp. 2.

27. Kiah Smith (2015) Collective empowerment? Producer cooperatives versus women's groups in Kenyan ethical trade. United Nations Research Institute for Social Development.

28. MacHenry R (2000) Building on local strategies: Nepalese fair-trade textiles. KM Grimes, BL Milgram (Ed), Artisans and cooperatives: Developing alternative trade for the global economy pp. 25-44.

29. McMurtry JJ, Schincariol L (2015) Advancing gender equality: The cooperative way. International Co-operative Alliance, International Labour Organization, Switzerland.

30. Maleko GN, Basili SA, Liheta, Deogratius Aikaruwa, Angelina Lukas, et al (2013) Women Participation in Microfinance Institutions of Tanzania: The Case of Savings and Credit Co-operative Societies (SACCOS). Journal of Business Administration and Education Moshi University College of Cooperative and Business Studies (MUCCOBS), Tanzania 4(2): 139-175.

31. Merriam-Webster

32. Mori PA (2015) Cooperation di community e la participation dei Cittadino alla gestione dei 5: 8-18.

33. Mori PA (2017) Community Co-operative and Co-operatives providing Public Services. Michie J, Blasi, J Borzaga C (Ed) The Oxford Handbook of Mutual. Co-operative, and Co-owned Business, Oxford University Press, US.

34. Mshiu Sam (2012) Empowering women through their own SACCO. Stories.coop.

35. Nippierd A (2002) Gender issues in cooperatives. International Labour Organization, Geneva, Switzerland.

36. SASRA (2018) The Sacco Supervision Annual Report is published by the Sacco Societies Regulatory Authority (SASRA) and is available from the Authority's website www.sasra.go.ke All Rights reserved (C) 2018 The SACCO Supervision Annual Report, 2017. 
37. The World Bank (2011) World Development Report. "The decline of the breadwinner: Men in the $21^{\text {st }}$ century, Gender Equality and Development Washington, US. p. 194-196.

38. Report of the Secretary-General, Special edition: progress towards the Sustainable Development Goals.

39. UNICEF (2014) Ending Child Marriage: Progress and Prospects, New York, US.
40. Wanyama FO (2014) Cooperatives and the Sustainable Development Goals. A Contribution to the Post-2015 Development Debate. A Policy Brief. International Cooperative Alliance, International Labour Organization, Geneva, Switzerland. 